\title{
Innovative work behavior of Vietnam telecommunication enterprise employees
}

\author{
Thị Phương Linh Nguyễn ${ }^{a^{*}}$
}

${ }^{a}$ National Economics University, Vietnam

\begin{tabular}{l}
\hline C H R O N I C L E \\
\hline Article history: \\
Received: March 4, 2019 \\
Received in revised format: April \\
92019 \\
Accepted: April 24, 2019 \\
Available online: \\
April 26, 2019 \\
\hline Keywords: \\
Innovative work behavior \\
Vietnam telecommunications en- \\
terprises \\
ASEAN countries
\end{tabular}

\section{Introduction}

International integration today is integrated into a globally connected knowledge economy: global business production, global supply chains, global value chains, etc. During the recent years, the development of the service sector in Vietnam has achieved many remarkable results, but still not commensurate with the potential and requirements of the country's economic development. The scale and quality of services in Vietnam is too low compared with other countries in the region and in the world, the speed of restructuring the economy in the direction of services is still very slow, the proportion of the service sector in growth domestic product (GDP) is almost unchanged compared with the previous five-year period of about $40 \%$ of GDP, which is much lower than $70-80 \%$ of GDP of developed economies. Knowledgeintensive service industries, which are regarded as "lifeline" of the economy such as finance - credit, science and technology, education and training, health are still accounted for small rate and the quality of growth is not high. In the service industries, telecommunication services include service providers with network infrastructure and service providers without network infrastructure as a social infrastructure that play important roles in boosting economic growth, increasing productivity and efficiency in rural agriculture, industry, social services, as well as improving the quality of life. During the past few years, the telecommunications industry has developed strongly, there are about 77 enterprises providing telecommunications services and 52 enterprises have provided Internet services in 2017, the total number of

\begin{abstract}
The telecommunications industry plays an important role in the socio-economic development. In ment in width without focusing on depth development. To aim for sustainable growth and deep (1) consider and implement innovative work behavior (IWB) novative work of individuals and colleagues. At the same time, the study also concluded that there communication enterprise employees when evaluating and scoring two scales of acts of innovation. Research results contributed both theoretically and practically to scholars and managers of Vietnam
\end{abstract} C 2019 by the authors; licensee Growing Science, Canada 
telephone subscribers is currently over 127 million devices, 10 times higher than 2005, the rate of broadband Internet subscribers reached 6.5 subscribers per 100 people, nearly 2 times higher than in 2010 and 30 times higher than 2005. Vietnam continues to be one of the fastest growing telecommunications markets in the region and the world over the past 10 years. However, the level of competition in Vietnam's telecommunication market is forecasted to be even fiercer as the market has entered a saturated period and more new service providers have appeared on the market according commitment implementation process. Besides, with the pervasive nature of the industrial revolution 4.0, the development of technology will be faster and stronger with remarkable changes. Therefore, Vietnam telecommunications enterprises need to focus on developing in depth, proactively promote innovation, exploit knowledge and develop technology to catch up with the continuous progress of technology and effectively capture the great opportunities that this revolution brings. The ability of an enterprise to innovate depends on the innovative work behavior (IWB) of each employee in the enterprise. When each employee recognizes and implements acts of innovation, Vietnam telecommunications enterprises have the opportunity to develop in depth and be able to compete in the knowledge economy and global integration. Therefore, the IWB of Vietnam telecommunication enterprise employees was chosen as the topic for the paper. In this study, the author focused on understanding the views of telecommunication enterprise employees on IWB and testing the differences between demographic variables when implementing IWB.

\section{Literature review}

\subsection{Innovative work behavior}

Innovation plays an important role for the existence of organizations that help create business models, management techniques, strategies and organizational structures in addition to new products or services (Turgut \& Beğenirbaş, 2013; McGuirk et al., 2015). One of the most effective ways to enhance organizations' innovation capabilities is to develop creativity and the ability to create new ideas for employees, namely IWB. Human capital is the basis for innovation and employee-based assessment of innovation is an important strategy to help managers cope with global competition and environmental instability, to achieve high targets and performance (Afsar et al., 2015; Wisse et al., 2015). IWB is defined as the behavior of employees to create, introduce and apply new ideas intentionally at work, a group or an organization that contributes to performance (Janssen, 2000). This behavior is intentional behavior of individuals to create and implement new and useful ideas to benefit individuals, groups or organizations (Bos-Nehles et al., 2017). It is also a process for creating new problem-solving applications that begin with problem identification, finding solutions and implementing organizational solutions (Turgut \& Beğenirbaş, 2013). Amo and Kolvereid (2005) define IWB as the ability to actively work to produce new products, find new markets, new processes and new combinations (Dhar, 2015). IWB is expected to produce innovative outcomes and thus benefit individuals, groups or organizations. Innovative outputs may include the expansion and innovation of products, services, processes, the development of new production methods and new management systems (Crossan \& Apaydin, 2010; Tidd, 2001). In order to carry out this behavior, the core is the creativity of the employees, but the behavior of innovation is more meaningful than creativity even though creativity is a necessary part of this behavior because of the creativity is only the ability to develop new ideas, but innovation also includes implementing these ideas (Scott \& Bruce, 1994). IWB is divided into two phases by Dorenbosch et al. (2005): inventing and implementing ideas; meanwhile Scott and Bruce (1994) divided into three phases: forming new and useful ideas, seeking support and implementing ideas that were formed and promoted. The first stage is conceptualization - employees identify problems and opportunities, seeking new ideas to act as solutions to problem solving; the second stage is called idea protection - the idea is promoted throughout the organization to seek support for the next development or in other words, group building, including individuals with the capacity needed to practice ideas; the third stage is idea practice - putting ideas into the promotion of daily business, group or organization work (Janssen, 2000). Based on the analysis into stages, the scale of innovate work behavior has been developed by a number of scholars such as Janssen (2000), De Jong and Den Hartog (2010) and Bysted (2013). All scales refer to proposing, seeking support and im- 
plementing innovative ideas of individual employees. In fact, innovative ideas can be formed by employees and their colleagues, while fundamental innovations are accomplished by individuals, while completing more complex innovations often requires work group based on diversity of knowledge, ability and job role (Janssen, 2000). Therefore, the establishment of IWB scales has the appearance of observations related to the participation of both employees and their colleagues in proposing, seeking support and implementing ideas are needed.

\subsection{Influence of demographic variables on innovative work behavior}

A meta-analysis by $\mathrm{Ng}$ and Feldman (2013) suggested that older employees were less involved in innovationrelated behaviors than younger peers. Similarly, Janssen (2000) found that IWB depends on employees' age. Frosch (2011) found empirical evidence to conclude that the highest level of innovation could be found in employees between the ages of 30 and 50 depending on their area of expertise. Ericsson (1999), Youndt et al. (1996) argued that innovation depends very much on the specific combination of knowledge and expertise of employees. Damanpour (1991) confirmed the diversity of skills and experiences that added significant value to innovation results. Highly educated employees with different backgrounds had an impact on creative behavior (Bantel \& Jackson, 1989). Meanwhile, work experience affected the outcome of work which includes IWB and was therefore very important to invest in further developing knowledge and skills for employees. Von Krogh et al. (2000) argued that demographic variables (gender, age and education qualification) affected the ability to innovate in an organization; Lee and Hong (2014) concluded that as the education level, position and work experience of workers increase, innovation behavior also tend to be positive. However, Baldridge and Burnham (1975) argued that demographic characteristics (gender, age, educational qualification) did not affect employee innovation behavior. De Jong and Den Hartog (2010) and Bysted (2013) in their study also confirmed that gender did not affect the employee's IWB. Yunus et al. (2014) showed no significant differences in IWB based on demographic factors such as gender, education qualification. Leong and Rasli (2014) concluded that gender and education qualification did not affect the IWB of individuals. Thus, the act of innovation was proven to have a relationship with demographic variables (gender, age, educational qualification, work experience) in some studies and no relationship in some other studies. With the research object being an employee in Vietnam telecommunications enterprises, the author decided to consider the impact of these demographic variables on IWB to determine their differences when evaluating these scales.

\section{Research methodology}

\subsection{Qualitative research}

Qualitative research was conducted through in-depth interviews with 5 Heads or Deputy Boards and 5 employees of telecommunications enterprises in Hanoi, Da Nang and Ho Chi Minh City of Vietnam. Interviews were conducted at the interviewee's workplace for about 1 hour. The content of the in-depth interview was recorded, stored and encrypted in the computer. Later, the recording was removed, synthesized and analyzed in order to learn about the IWB of Vietnam telecommunication enterprise employees. The results of qualitative research showed that each employee should be encouraged to come up with new ideas that apply to the job. Some interviewees admitted that they had proposed new ideas and applied them to their daily work. The work of telecommunications enterprise employees promotes interpersonal interaction when performing certain tasks and this interaction sometimes helps new ideas to be implemented in practice to benefit useful for enterprises. The answer to clarifying the IWB of telecommunications enterprise employees was:

"We face a lot of pressure at work. Many times being urged by customers to hand over, we are forced to constantly seeking ways to speed up. Innovating workflows, upgrading network software, deploying backup systems are things that I have personally proposed and received the support of managers for widespread implementation in the company" ( Staff, 6 - 10 years of experience).

"I always encouraged my subordinates to come up with new ideas because it was time-consuming and sometimes not feasible to deploy in the old way. Some young people are quite positive and they have repeatedly proposed to me the working method to shorten the implementation time, complete the assigned 
schedule soon" (Head, 6 - 10 years of experience).

"I think the new idea can be made by individuals or individuals and colleagues after exchanging suggestions. Complex ideas require the help and contribution of many individuals, but one cannot make and deploy" (Staff, 1 - 5 years of experience).

"Once I and my close colleague asked the question of why not upgrade and maximize the company's network and data. We worked together to find solutions and get support from people for a wide range of deployment" (Staff, 6-10 years of experience).

"The last time I and my colleagues came up with a new idea was to propose a form to collect information and manage the project. This form was then applied not only in my department but also by other departments" (Deputy Boards, 6 - 10 years of experience).

"I often have a habit of talking to colleagues and willing to tell colleagues what I know. I think that will give us the opportunity to discuss and find new ways to work more effectively" (Staff, 6-10 years of experience).

"The positive employees exchanging with colleagues often actively connect with colleagues, establish innovation groups in the enterprise. Many initiatives come from these groups, I think should encourage such groups because a person is not easy to find new solutions that are useful for the enterprise" (Head, over 15 years of experience).

Therefore, IWB takes place regularly in the work of Vietnam telecommunication enterprise employees. Interview results showed that this behavior was not only accomplished by individuals but also by a combination of individuals and their colleagues. Therefore, the behavior of innovation should be considered by two scales including the behavior of innovative work of individuals, the behavior of innovative work of individuals and colleagues.

\subsection{Quantitative research}

Quantitative research was conducted through a survey with a sample of employees currently working in telecommunications enterprises in the North, Central and South of Vietnam, specifically the author conducted a total of 30 telecommunications enterprises across the country, accounting for about $40 \%$ of the total number of telecommunications service providers currently doing business. The survey was conducted in July \& August 2018. The author chose samples in a convenient way and the research sample tried to be distributed according to the North, Central and South regions. In addition, the selection of the research sample was be appropriately allocated according to demographic factors to ensure comparison in the results obtained. IWB was described by the two scales: the behavior of innovative work of individuals (4 observations) and the behavior of innovative work of individuals and colleagues (4 observations). Each scale used 4 observations to investigate, these 4 observations were respectively inherited and inherited from the studies of Scott and Bruce (1994), Janssen (2000) and Bysted (2013). Variables were measured by Likert scale from 1 (completely disagree) to 5 (completely agree).

Table 1

The scale of IWB

\begin{tabular}{|c|c|c|}
\hline No. & Scale & Items \\
\hline \multirow{4}{*}{1} & \multirow{4}{*}{ The behavior of innovative work of individuals } & I create new ideas for improvement \\
\hline & & I am always looking for new methods, techniques or tools \\
\hline & & I work hard to test new ideas \\
\hline & & I convert innovative ideas into useful applications \\
\hline \multirow{4}{*}{2} & \multirow{4}{*}{$\begin{array}{l}\text { The behavior of innovative work of individuals } \\
\text { and colleagues }\end{array}$} & I and my colleagues exchange ideas to create new ideas for improvement \\
\hline & & I and my colleagues talk to each other to find new methods, techniques or tools \\
\hline & & I and my colleagues work hard together to test new ideas \\
\hline & & I and my colleagues together convert innovative ideas into useful applications \\
\hline
\end{tabular}

With the survey results, the author used descriptive statistical method with the support of SPSS 22.0 software to analyze the IWB of Vietnam telecommunication enterprise employees and conduct the verification differences in demographic variables when evaluating IWB. 


\section{Results}

\subsection{Describe the research sample}

Table 2

Statistics of quantitative research samples

\begin{tabular}{|c|c|c|c|c|c|}
\hline Category & $\begin{array}{l}\text { Number of } \\
\text { respondents }\end{array}$ & Percentages (\%) & Category & $\begin{array}{l}\text { Number of } \\
\text { respondents }\end{array}$ & Percentages (\%) \\
\hline Gender & 396 & 100 & Education qualification & 396 & 100 \\
\hline Male & 243 & 61,4 & Intermediate & 57 & 14,4 \\
\hline \multirow[t]{2}{*}{ Female } & \multirow[t]{2}{*}{153} & \multirow[t]{2}{*}{38,6} & Bachelor & 254 & 64,1 \\
\hline & & & Master or doctor & 85 & 21,5 \\
\hline Age & 396 & 100 & Work experience & 396 & 100 \\
\hline From 20 to 30 & 135 & 34,1 & Under 1 year & 33 & 8,3 \\
\hline From 31 to 45 & 191 & 48,2 & From 1 to 5 years & 82 & 20,7 \\
\hline \multirow[t]{3}{*}{ From 46 to 60} & 70 & 17,7 & From 6 to 10 years & 183 & 46,2 \\
\hline & & & From 11 to 15 years & 61 & 15,4 \\
\hline & & & Over 15 years & 37 & 9.4 \\
\hline
\end{tabular}

The statistics of the 396 observed in the official quantitative research show that the sample of telecommunication enterprise employees after further investigation was mainly male (accounting for 61.4\%); most of them were in the age group from 31 to 45 (accounting for $48.2 \%$ ), then to the age group from 20 to 30 (accounting for $34.1 \%$ ); education qualification of the surveyed employees had mainly bachelor degree (accounting for 64.1\%); the number of employees with 6 to 10 years of work experience accounted for nearly half of the total number of observations, namely $46.2 \%$; followed by 1 to 5 years, accounting for $20.7 \%$.

\subsection{Descriptive statistics results}

Analysis by gender

Table 3

Statistics describing the scales divided by gender

\begin{tabular}{cccrrr}
\hline & & $\mathrm{N}$ & Mean & Std. Deviation & Std. Error \\
\hline \multirow{2}{*}{ The behavior of innovative work of individuals } & Male & 243 & 3.2685 & 0.98105 & 0.06293 \\
& Female & 153 & 3.4346 & 1.08244 & 0.08751 \\
\cline { 2 - 7 } & Total & 396 & 3.3327 & 1.02328 & 0.05142 \\
\hline \multirow{2}{*}{ The behavior of innovative work of individuals and colleaguesFemale } & 153 & 3.4804 & 0.86770 & 0.07015 \\
\cline { 2 - 6 } & Male & 243 & 2.7891 & 0.86723 & 0.05563 \\
\hline
\end{tabular}

The statistical results describing the research sample in Table 3 show that the average assessment score of the male group was lower than that of the female group when evaluating the behavior of innovative work of individuals, the behavior of innovative work of individuals and colleagues.

\section{Table 4}

Testing differences by gender

\begin{tabular}{|c|c|c|c|c|c|c|}
\hline & & Sum of Squares & $\mathrm{df}$ & Mean Square & $\mathrm{F}$ & Sig. \\
\hline \multirow{3}{*}{$\begin{array}{l}\text { The behavior of innovativ } \\
\text { work of individuals }\end{array}$} & Between Groups & 2,591 & 1 & 2,591 & 2,484 & 0,116 \\
\hline & Within Groups & 411,013 & 394 & 1,043 & & \\
\hline & Total & 413,604 & 395 & & & \\
\hline \multirow{3}{*}{$\begin{array}{c}\text { The behavior of innovative } \\
\text { work of individuals and } \\
\text { colleagues }\end{array}$} & Between Groups & 44,868 & 1 & 44,868 & 59,633 & 0,000 \\
\hline & Within Groups & 296,445 & 394 & 0,752 & & \\
\hline & Total & 341,312 & 395 & & & \\
\hline
\end{tabular}

In order to confirm whether or not there is a difference in gender for the behavior of innovative work of individuals, the behavior of innovative work of individuals and colleagues is performed through the method of variance analysis (ANOVA) with assumption pair:

$\mathrm{H}_{0}$ : There is no variance difference between gender groups.

$\mathrm{H}_{1}$ : There is a variance difference between gender groups. 
ANOVA analysis results are presented in Table 4, and with the results obtained from the survey sample, it can be seen that there were significant differences between the groups by gender when assessing the innovative working behavior of individuals and colleagues when the level of significance is five percent; for the behavior of individual innovation, the difference between men and women was not meaningful different when the level of significance is five percent.

Analysis by age

Table 5

Statistics describe the scales divided by age

\begin{tabular}{clcccc}
\hline & & N & Mean & Std. Deviation & Std. Error \\
\hline \multirow{2}{*}{$\begin{array}{c}\text { The behavior of innovative } \\
\text { work of individuals }\end{array}$} & From 20 to 30 & 135 & 3.3111 & 0.96558 & 0.08310 \\
& From 31 to 45 & 191 & 3.4503 & 1.03371 & 0.07480 \\
& From 46 to 60 & 70 & 3.0536 & 1.05971 & 0.12666 \\
\cline { 2 - 6 } & Total & 396 & 3.3327 & 1.02328 & 0.05142 \\
\hline \multirow{2}{*}{$\begin{array}{c}\text { The behavior of innovative } \\
\text { work of individuals and } \\
\text { colleagues }\end{array}$} & From 20 to 30 & 135 & 2.6667 & 0.80923 & 0.06965 \\
& From 31 to 45 & 191 & 3.2958 & 0.95501 & 0.06910 \\
\cline { 2 - 6 } & From 46 to 60 & 70 & 3.1536 & 0.83546 & 0.09986 \\
\hline
\end{tabular}

The statistical results describing the research sample in Table 5 show that scores of 31-45 year olds scored higher on both scales of IWB than other groups. The results of testing the differences between age groups are presented in Table 6, which show that there was a meaningful difference between age groups in the respondents' assessment of the behavior of innovative work of individuals, the behavior of innovative work of individuals and colleagues when the level of significance is five percent.

Table 6

Testing differences between age groups (ANOVA)

\begin{tabular}{|c|c|c|c|c|c|}
\hline & Sum of Squares & df & Mean Square & $\mathbf{F}$ & Sig. \\
\hline \multirow{3}{*}{$\begin{array}{l}\text { The behavior of inno- } \\
\text { vative work of indi- } \\
\text { viduals }\end{array}$} & 8.157 & 2 & 4.078 & 3.953 & 0.020 \\
\hline & 405.447 & 393 & 1.032 & & \\
\hline & 413.604 & 395 & & & \\
\hline The behavior of inno- Between Groups & 32.114 & 2 & 16.057 & 20.409 & 0.000 \\
\hline vative work of individ-Within Groups & 309.198 & 393 & 0.787 & & \\
\hline uals and colleagues & 341.312 & 395 & & & \\
\hline
\end{tabular}

Results of assessment of differences between age groups are presented in detais in Table 7 for in-depth analysis (Post Hoc) to assess whether the actual differences are age groups. Any results of the actual differences in age groups are marked with *. Specifically:

Table 7

Analyzing differences by age group when evaluating IWB

\begin{tabular}{|c|c|c|c|c|c|c|c|}
\hline \multirow{2}{*}{ Dependent Variable } & \multirow{2}{*}{ (I) Age } & \multirow{2}{*}{ (J) Age } & \multirow{2}{*}{$\begin{array}{l}\text { Mean Differ- } \\
\text { ence (I-J) }\end{array}$} & \multirow{2}{*}{ Std. Error } & \multirow{2}{*}{ Sig. } & \multicolumn{2}{|c|}{$95 \%$ Confidence Interval } \\
\hline & & & & & & Lower Bound & Upper Bound \\
\hline \multirow{6}{*}{$\begin{array}{l}\text { The behavior of innova- } \\
\text { tive work of individuals }\end{array}$} & \multirow{2}{*}{ From 20 to 30} & From 31 to 45 & -.13915 & .11421 & .671 & -.4137 & .1354 \\
\hline & & From 46 to 60 & .25754 & .14960 & .258 & -.1021 & .6172 \\
\hline & \multirow{2}{*}{ From 31 to 45} & From 20 to 30 & .13915 & .11421 & .671 & -.1354 & .4137 \\
\hline & & From 46 to 60 & $.39669^{*}$ & .14191 & .016 & .0555 & .7379 \\
\hline & \multirow{2}{*}{ From 46 to 60} & From 20 to 30 & -.25754 & .14960 & .258 & -.6172 & .1021 \\
\hline & & From 31 to 45 & $-.39669^{*}$ & .14191 & .016 & -.7379 & -.0555 \\
\hline \multirow{6}{*}{$\begin{array}{l}\text { The behavior of innova- } \\
\text { tive work of individuals } \\
\text { and colleagues }\end{array}$} & \multirow{2}{*}{ From 20 to 30} & From 31 to 45 & $-.62914^{*}$ & .09973 & .000 & -.8689 & -.3894 \\
\hline & & From 46 to 60 & $-.48690^{*}$ & .13064 & .001 & -.8010 & -.1728 \\
\hline & \multirow{2}{*}{ From 31 to 45} & From 20 to 30 & $.62914^{*}$ & .09973 & .000 & .3894 & .8689 \\
\hline & & From 46 to 60 & .14224 & .12393 & .755 & -.1557 & .4402 \\
\hline & \multirow{2}{*}{ From 46 to 60} & From 20 to 30 & $.48690^{*}$ & .13064 & .001 & .1728 & .8010 \\
\hline & & From 31 to 45 & -.14224 & .12393 & .755 & -.4402 & .1557 \\
\hline
\end{tabular}

\footnotetext{
*. The mean difference is significant at the 0.05 level.
} 
For the behavior of innovative work of individuals, there was a real difference between the age group 31 - 45 and the age group of 46-60 because the P-value value is 0.016 and less than 0.05.

For the behavior of innovative work of individuals and colleagues, the difference took place between the age group of 20-30 years compared with the other two age groups (from 31 - 45 years old and from 4660 years old). The results of the in-depth analysis show that the group of 20-30 years old evaluated the behavior of innovative work of individuals and colleagues lower than the other two groups.

\section{Analysis by education qualification}

The statistical results describing the research sample in Table 8 show that the group with bachelor degree scored higher on two scales compared to other groups.

Table 8

Statistics describe the scales divided by education qualification

\begin{tabular}{|c|c|c|c|c|c|c|c|}
\hline & & \multirow[t]{2}{*}{$\mathrm{N}$} & \multirow[t]{2}{*}{ Mean } & \multirow{2}{*}{$\begin{array}{c}\text { Std. } \\
\text { Deviation }\end{array}$} & \multirow{2}{*}{$\begin{array}{l}\text { Std. } \\
\text { Error }\end{array}$} & \multicolumn{2}{|c|}{$\begin{array}{l}\text { 95\% Confidence Interval for } \\
\text { Mean }\end{array}$} \\
\hline & & & & & & Lower Bound & Upper Bound \\
\hline \multirow{4}{*}{$\begin{array}{l}\text { The behavior of innova- } \\
\text { tive work of individuals }\end{array}$} & Intermediate & 57 & 2.6316 & .89156 & .11809 & 2.3950 & 2.8681 \\
\hline & Bachelor & 254 & 3.6152 & .90632 & .05687 & 3.5032 & 3.7272 \\
\hline & Master or doctor & 85 & 2.9588 & 1.09711 & .11900 & 2.7222 & 3.1955 \\
\hline & Total & 396 & 3.3327 & 1.02328 & .05142 & 3.2316 & 3.4338 \\
\hline \multirow{4}{*}{$\begin{array}{l}\text { The behavior of innova- } \\
\text { tive work of individuals } \\
\text { and colleagues }\end{array}$} & Intermediate & 57 & 2.0132 & .63285 & .08382 & 1.8452 & 2.1811 \\
\hline & Bachelor & 254 & 3.2825 & .84884 & .05326 & 3.1776 & 3.3874 \\
\hline & Master or doctor & 85 & 3.0794 & .85584 & .09283 & 2.8948 & 3.2640 \\
\hline & Total & 396 & 3.0562 & .92956 & .04671 & 2.9644 & 3.1480 \\
\hline
\end{tabular}

The results of testing the difference in education qualification presented in Table 9 show that there was a meaningful difference in education qualification in the respondents' assessment of the behavior of innovative work of individuals, the behavior of innovative work of individuals and colleagues when the level of significance is five percent.

Table 9

Testing differences by education qualification (ANOVA)

\begin{tabular}{|c|c|c|c|c|c|c|}
\hline & & Sum of Squares & $\mathrm{df}$ & Mean Square & $\mathrm{F}$ & Sig. \\
\hline \multirow{3}{*}{$\begin{array}{l}\text { The behavior of innovative } \\
\text { work of individuals }\end{array}$} & Between Groups & 60.166 & 2 & 30.083 & 33.450 & 0.000 \\
\hline & Within Groups & 353.438 & 393 & 0.899 & & \\
\hline & Total & 413.604 & 395 & & & \\
\hline \multirow{3}{*}{$\begin{array}{c}\text { The behavior of innovative } \\
\text { work of individuals and } \\
\text { colleagues }\end{array}$} & Between Groups & 75.064 & 2 & 37.532 & 55.399 & 0.000 \\
\hline & Within Groups & 266.249 & 393 & 0.677 & & \\
\hline & Total & 341.312 & 395 & & & \\
\hline
\end{tabular}

The results of assessment of differences in education qualification are presented in Table 10 for in-depth analysis (Post Hoc) to assess whether the actual differences are in the groups with such education levels. Any results of the actual differences in education qualification are marked with a $*$. Specifically:

- For the behavior of innovative work of individuals, there were differences between subjects with different levels of education, in which the behavior of innovative work of individuals is evaluated and scored higher by the subjects with master/doctor and intermediate levels compared to those with bachelor degrees.

- For the behavior of innovative work of individuals and colleagues, there were differences between subjects with different levels of education, in which the behavior of innovative work of individuals and colleagues is evaluated and higher scores by the subjects with intermediate level compared to those with bachelor degree and those with master/doctor degrees. 
Table 10

Analyzing differences by education qualification when evaluating IWB

\begin{tabular}{|c|c|c|c|c|c|c|c|}
\hline \multirow{2}{*}{ Dependent Variable } & \multirow{2}{*}{$\begin{array}{l}\text { (I) Education } \\
\text { qualification }\end{array}$} & \multirow{2}{*}{$\begin{array}{l}\text { (J) Education } \\
\text { qualification }\end{array}$} & \multirow{2}{*}{$\begin{array}{c}\text { Mean } \\
\text { Difference } \\
(\mathrm{I}-\mathrm{J})\end{array}$} & \multirow{2}{*}{$\begin{array}{l}\text { Std. } \\
\text { Error }\end{array}$} & \multirow{2}{*}{ Sig. } & \multicolumn{2}{|c|}{$\begin{array}{l}95 \% \text { Confidence } \\
\text { Interval }\end{array}$} \\
\hline & & & & & & $\begin{array}{l}\text { Lower } \\
\text { Bound }\end{array}$ & $\begin{array}{l}\text { Upper } \\
\text { Bound }\end{array}$ \\
\hline \multirow{6}{*}{$\begin{array}{l}\text { The behavior of innova- } \\
\text { tive work of individuals }\end{array}$} & \multirow{2}{*}{ Intermediate } & Bachelor & $-.98358^{*}$ & .13899 & .000 & -1.3178 & -.6494 \\
\hline & & Master/doctor & -.32724 & .16235 & .134 & -.7176 & .0631 \\
\hline & \multirow{2}{*}{ Bachelor } & Intermediate & $.98358^{*}$ & .13899 & .000 & .6494 & 1.3178 \\
\hline & & Master/doctor & $.65633^{*}$ & .11883 & .000 & .3706 & .9420 \\
\hline & \multirow[b]{2}{*}{ Master/doctor } & Intermediate & .32724 & .16235 & .134 & -.0631 & .7176 \\
\hline & & Bachelor & $-.65633^{*}$ & .11883 & .000 & -.9420 & -.3706 \\
\hline \multirow{6}{*}{$\begin{array}{l}\text { The behavior of innova- } \\
\text { tive work of individuals } \\
\text { and colleagues }\end{array}$} & \multirow{2}{*}{ Intermediate } & Bachelor & $-1.26932^{*}$ & .12064 & .000 & -1.5594 & -.9793 \\
\hline & & Master/doctor & $-1.06625^{*}$ & .14091 & .000 & -1.4050 & -.7275 \\
\hline & \multirow{2}{*}{ Bachelor } & Intermediate & $1.26932^{*}$ & .12064 & .000 & .9793 & 1.5594 \\
\hline & & Master/doctor & .20307 & .10314 & .149 & -.0449 & .4510 \\
\hline & \multirow{2}{*}{ Master/doctor } & Intermediate & $1.06625^{*}$ & .14091 & .000 & .7275 & 1.4050 \\
\hline & & Bachelor & -.20307 & .10314 & .149 & -.4510 & .0449 \\
\hline
\end{tabular}

*. The mean difference is significant at the 0.05 level.

\section{Analysis by work experience}

The statistical results describing the research sample in Table 11 show the average assessment score of the respondents with 6 to 10 years of working experience giving the highest score in the behavior of innovative work of individuals compared to the other groups. Meanwhile, the average score of those with experience of working for more than 15 years gave the highest score in the behavior of innovative work of individuals and colleagues compared to other groups.

Table 11

Statistics describe the scales divided by work experience

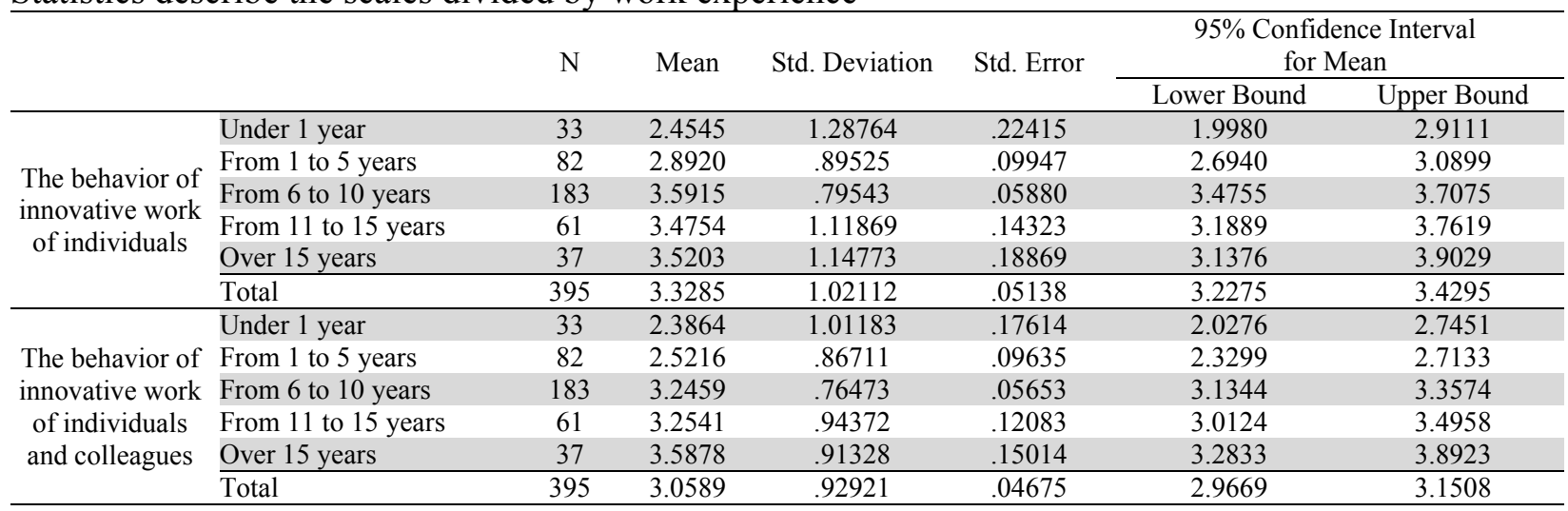

The results of testing the differences in work experience presented in Table 12 show that there was a meaningful difference in work experience in the respondents' assessment of the behavior of innovative work of individuals, the behavior of innovative work of individuals and colleagues when the level of significance is five percent.

Table 12

Testing differences by work experience (ANOVA)

\begin{tabular}{llccccc}
\hline & & Sum of Squares & df & Mean Square & F & Sig. \\
\hline \multirow{2}{*}{$\begin{array}{l}\text { The behavior of innovative } \\
\text { work of individuals }\end{array}$} & Between Groups & 55,978 & 4 & 13,995 & 15,381 & 0,000 \\
\cline { 2 - 6 } & Within Groups & 354,839 & 390 & 0,910 & & \\
\hline \multirow{2}{*}{$\begin{array}{l}\text { The behavior of innovative } \\
\text { work of individuals and col- } \\
\text { leagues }\end{array}$} & Between Groups & 410,817 & 394 & & & \\
\cline { 2 - 7 } & Within Groups & 57,385 & 4 & 14,346 & 19,784 & 0,000 \\
\hline
\end{tabular}


The results of the assessment of differences according to work experience are presented in details in Table 13 for in-depth analysis (Post Hoc) to assess whether there is meaningful difference among the groups of people with such experience. Any results of the actual differences in work experience are marked with a *. Specifically:

- For the behavior of innovative work of individuals, there was a difference between the objects with different work experience, the behavior of innovative work of individuals was evaluated and scored higher by the objects with experience of less than 1 year, 1-5 years compared to those with work experience of 6-10 years, 11-15 years, over 15 years.

- For the behavior of innovative work of individuals and colleagues, there was a difference between the objects with different work experience, in which the behavior of innovative work of individuals and colleagues was evaluated and score higher because the group has under 1 year, 1-5 year working experience compared to those with 6-10 year, 11-15 year, over 15 year working experience.

Table 13

Analyzing differences by work experience when evaluating IWB

\begin{tabular}{|c|c|c|c|c|c|c|c|}
\hline \multirow{2}{*}{ Dependent Variable } & \multirow{2}{*}{ (I) Work experience } & \multirow{2}{*}{$\begin{array}{l}\text { (J) Work } \\
\text { experience }\end{array}$} & \multirow{2}{*}{$\begin{array}{c}\text { Mean } \\
\text { Difference } \\
\quad(\mathrm{I}-\mathrm{J})\end{array}$} & \multirow{2}{*}{ Std. Error } & \multirow{2}{*}{ Sig. } & \multicolumn{2}{|c|}{$\begin{array}{l}\text { 95\% Confidence } \\
\text { Interval }\end{array}$} \\
\hline & & & & & & $\begin{array}{l}\text { Lower } \\
\text { Bound }\end{array}$ & $\begin{array}{l}\text { Upper } \\
\text { Bound }\end{array}$ \\
\hline \multirow{20}{*}{$\begin{array}{c}\text { The behavior of innovative } \\
\text { work of individuals }\end{array}$} & \multirow{4}{*}{ Under 1 year } & $1-5$ years & -.43743 & .19699 & .270 & -.9935 & .1187 \\
\hline & & $6-10$ years & $-1.13698^{*}$ & .18040 & .000 & -1.6463 & -.6277 \\
\hline & & $11-15$ years & $-1.02086^{*}$ & .20612 & .000 & -1.6028 & -.4390 \\
\hline & & Over 15 years & $-1.06572^{*}$ & .22839 & .000 & -1.7105 & -.4210 \\
\hline & \multirow{4}{*}{ From 1 to 5 years } & Under 1 year & .43743 & .19699 & .270 & -.1187 & .9935 \\
\hline & & $6-10$ years & $-.69955^{*}$ & .12730 & .000 & -1.0589 & -.3402 \\
\hline & & $11-15$ years & $-.58343^{*}$ & .16170 & .003 & -1.0399 & -.1269 \\
\hline & & Over 15 years & $-.62829^{*}$ & .18927 & .010 & -1.1626 & -.0940 \\
\hline & \multirow{4}{*}{ From 6 to 10 years } & Under 1 year & $1.13698^{*}$ & .18040 & .000 & .6277 & 1.6463 \\
\hline & & $1-5$ years & $.69955^{*}$ & .12730 & .000 & .3402 & 1.0589 \\
\hline & & $11-15$ years & .11612 & .14102 & 1.000 & -.2820 & .5142 \\
\hline & & Over 15 years & .07126 & .17194 & 1.000 & -.4141 & .5567 \\
\hline & \multirow{4}{*}{ From 11 to 15 years } & Under 1 year & $1.02086^{*}$ & .20612 & .000 & .4390 & 1.6028 \\
\hline & & $1-5$ years & $.58343^{*}$ & .16170 & .003 & .1269 & 1.0399 \\
\hline & & $6-10$ years & -.11612 & .14102 & 1.000 & -.5142 & .2820 \\
\hline & & Over 15 years & -.04486 & .19876 & 1.000 & -.6060 & .5163 \\
\hline & \multirow{4}{*}{ Over 15 years } & Under 1 year & $1.06572^{*}$ & .22839 & .000 & .4210 & 1.7105 \\
\hline & & 1 - 5 years & $.62829^{*}$ & .18927 & .010 & .0940 & 1.1626 \\
\hline & & $6-10$ years & -.07126 & .17194 & 1.000 & -.5567 & .4141 \\
\hline & & $11-15$ years & .04486 & .19876 & 1.000 & -.5163 & .6060 \\
\hline \multirow{20}{*}{$\begin{array}{c}\text { The behavior of innovative } \\
\text { work of individuals and } \\
\text { colleagues }\end{array}$} & \multirow{4}{*}{ Under 1 year } & $1-5$ years & -.13524 & .17586 & 1.000 & -.6317 & .3612 \\
\hline & & $6-10$ years & $-.85954^{*}$ & .16105 & .000 & -1.3142 & -.4049 \\
\hline & & $11-15$ years & $-.86773^{*}$ & .18402 & .000 & -1.3872 & -.3482 \\
\hline & & Over 15 years & $-1.20147^{*}$ & .20389 & .000 & -1.7771 & -.6259 \\
\hline & \multirow{4}{*}{ From 1 to 5 years } & Under 1 year & .13524 & .17586 & 1.000 & -.3612 & .6317 \\
\hline & & $6-10$ years & $-.72430^{*}$ & .11364 & .000 & -1.0451 & -.4035 \\
\hline & & 11 - 15 years & $-.73249^{*}$ & .14436 & .000 & -1.1400 & -.3249 \\
\hline & & Over 15 years & $-1.06623^{*}$ & .16897 & .000 & -1.5433 & -.5892 \\
\hline & \multirow{4}{*}{ From 6 to 10 years } & Under 1 year & $.85954^{*}$ & .16105 & .000 & .4049 & 1.3142 \\
\hline & & 1 - 5 years & $.72430^{*}$ & .11364 & .000 & .4035 & 1.0451 \\
\hline & & $11-15$ years & -.00820 & .12590 & 1.000 & -.3636 & .3472 \\
\hline & & Over 15 years & -.34194 & .15350 & .265 & -.7753 & .0914 \\
\hline & \multirow{4}{*}{ From 11 to 15 years } & Under 1 year & $.86773^{*}$ & .18402 & .000 & .3482 & 1.3872 \\
\hline & & $1-5$ years & $.73249^{*}$ & .14436 & .000 & .3249 & 1.1400 \\
\hline & & $6-10$ years & .00820 & .12590 & 1.000 & -.3472 & .3636 \\
\hline & & Over 15 years & -.33374 & .17744 & .607 & -.8347 & .1672 \\
\hline & \multirow{4}{*}{ Over 15 years } & Under 1 year & $1.20147^{*}$ & .20389 & .000 & .6259 & 1.7771 \\
\hline & & $1-5$ years & $1.06623^{*}$ & .16897 & .000 & .5892 & 1.5433 \\
\hline & & $6-10$ years & .34194 & .15350 & .265 & -.0914 & .7753 \\
\hline & & $11-15$ years & .33374 & .17744 & .607 & -.1672 & .8347 \\
\hline
\end{tabular}

*. The mean difference is significant at the 0.05 level. 


\section{Discussion and conclusion}

Firstly, qualitative research has shown that IWB of Vietnam telecommunication enterprise employees should be divided into two scales, which are the behavior of innovative work of individuals and the behavior of innovative work of individuals and colleagues. In an enterprise, new ideas and proposals can be given by individuals or individuals with colleagues. Implementing ideas, applying ideas to work practices require the cooperation of a group of individuals and colleagues. This conclusion is consistent with the judgment of Janssen (2000) in his research.

Secondly, quantitative research shows differences in gender, age, education qualification and work experience when assessing the behavior of innovative work of individuals and the behavior of innovative work of individuals and colleagues.

- Gender difference: there was a gender difference when assessing the behavior of innovative work with individuals and colleagues. Between male and female employees, female employees tended to evaluate this scale at a higher level of consent than male employees. Some previous studies have confirmed this including Elsass and Graves (1997), Miller and Karakowsky (2005), Bordia et al. (2006), Lin (2007), Pangil and Nasrudin (2008), Boateng et al. (2015), GrubićNešić et al. (2015) and Killingsworth et al. (2016).

- Age difference: there was a difference between age groups when assessing the behavior of innovative work of individuals and the behavior of innovative work of individuals and colleagues. At a certain age, the ability to innovate at work was also different. In particular, when conducting in-depth analysis of the results show that the youngest group of employees (20-30 years old) tended to evaluate the IWB of individuals and colleagues lower than the two older groups (31-45 and 46-60 years old). Employees over the age of 31 tended to value communication with colleagues to make, apply new ideas in work than younger colleagues. Conclusions on differences between age groups when evaluating IWB have been mentioned in a number of studies such as: Janssen (2000), Frosch (2011), Ng and Feldman (2013).

- Education qualification difference: there was a difference in education qualification when assessing the behavior of innovative work of individuals and the behavior of innovative work of individuals and colleagues. The group of people with master/doctor and intermediate level evaluated and rated the innovation behavior of individuals higher than those with bachelor level; group of people with intermediate level assessed and gave points of innovation behavior of individuals and colleagues higher than those with bachelor and master/doctor levels. Conclusion of differences in educational qualification when assessing IWB was reacher by Youndt et al. (1996), Ericsson (1999), Von Krogh et al. (2000), Lee and Hong (2014).

- Work experience difference: there was a difference in work experience when assessing the behavior of innovative work of individuals and the behavior of innovative work of individuals and colleagues. The group of people with working experience of 5 years or less tended to score higher than those with work experience of 6 years or more for both scales. Newly inexperienced employees often actively learn and exchange with colleagues, want to assert themselves by proposing and applying new ideas at work. The more experienced employees are often difficult to find and often work by habit, so they do not pay much attention to proposing and applying new ideas at work. Affirming that there is a difference in work experience when assessing the behavior of innovation has also been mentioned in the study of Lee and Hong (2014).

This study provides both theoretical and practical contributions for researchers and business managers. In theory, scholars should consider the behavior of innovation according to both the behavior of innovative work of individuals and the behavior of innovative work of individuals and colleagues. In practice, managers need to pay attention to promoting the IWB of individuals but still need to consider promoting interaction between individuals and colleagues when implementing this behavior as well as being aware of differences in gender, age, education qualification and work experience of employees when performing these actions to take appropriate human resource management measures. 


\section{Acknowledgement}

This research is funded by National Economics University, Hanoi, Vietnam.

\section{References}

Afsar, B., Badir, Y., \& Khan, M. M. (2015). Person-job fit, person-organization fit and innovative work behavior: The mediating role of innovation trust. The Journal of High Technology Management Research, 26(2), 105-116.

Åmo, B. W., \& Kolvereid, L. (2005). Organizational strategy, individual personality and innovation behavior. Journal of Enter

Baldridge, J. V., \& Burnham, R. A. (1975). Organizational innovation: Individual, organizational, and environmental impacts. Administrative Science Quarterly, 20(2), 165-176.

Bantel, K. A., \& Jackson, S. E. (1989). Top management and innovations in banking: does the composition of the top team make a difference?. Strategic Management Journal, 10(S1), 107-124.

Bos-Nehles, A., Renkema, M., \& Janssen, M. (2017). HRM and innovative work behaviour: A systematic literature review. Personnel Review, 46(7), 1228-1253.

Bysted, R. (2013). Innovative employee behaviour: the moderating effects of mental involvement and job satisfaction on contextual variables. European Journal of Innovation Management, 16(3), 268284.

Crossan, M. M., \& Apaydin, M. (2010). A multi-dimensional framework of organizational innovation: A systematic review of the literature. Journal of Management Studies, 47(6), 1154-1191.

Damanpour, F. (1991). Organizational innovation: A meta-analysis of effects of determinants and moderators. Academy of Management Journal, 34(3), 555-590.

De Jong, J., \& Den Hartog, D. (2010). Measuring innovative work behaviour. Creativity and Innovation Management, 19(1), 23-36.

Dhar, R. L. (2015). The effects of high performance human resource practices on service innovative behaviour. International Journal of Hospitality Management, 51, 67-75.

Dorenbosch, L., Engen, M. L. V., \& Verhagen, M. (2005). On-the-job innovation: The impact of job design and human resource management through production ownership. Creativity and Innovation Management, 14(2), 129-141.

Ericsson, K. A. (1999). Creative expertise as superior reproducible performance: Innovative and flexible aspects of expert performance. Psychological Inquiry, 10(4), 329-333.

Frosch, K. H. (2011). Workforce age and innovation: a literature survey. International Journal of Management Reviews, 13(4), 414-430.

Janssen, O. (2000). Job demands, perceptions of effort-reward fairness and innovative work behaviour. Journal of Occupational and Organizational Psychology, 73(3), 287-302.

Lee, H. S., \& Hong, S. A. (2014). Factors affecting hospital employees' knowledge sharing intention and behavior, and innovation behavior. Osong Public Health and Research Perspectives, 5(3), 148-155.

Leong, C. T., \& Rasli, A. (2014). The Relationship between innovative work behavior on work role performance: An empirical study. Procedia-Social and Behavioral Sciences, 129, 592-600.

Martín Hernández, P., Salanova, M., \& Peiró, J. M. (2007). Job demands, job resources and individual innovation at work: Going beyond Karasek s model?. Psicothema, 19(4).

McGuirk, H., Lenihan, H., \& Hart, M. (2015). Measuring the impact of innovative human capital on small firms' propensity to innovate. Research Policy, 44(4), 965-976.

Ng, T. W., \& Feldman, D. C. (2013). A meta-analysis of the relationships of age and tenure with innovation-related behaviour. Journal of Occupational and Organizational Psychology, 86(4), 585-616.

Scott, S. G., \& Bruce, R. A. (1994). Determinants of innovative behavior: A path model of individual innovation in the workplace. Academy of Management Journal, 37(3), 580-607.

Tidd, J. (2001). Innovation management in context: environment, organization and performance. International Journal of Management Reviews, 3(3), 169-183. 
Turgut, E., \& Beğenirbaş, M. (2013). Çalışanların yenilikçi davranışları üzerinde sosyal sermaye ve yenilikçi iklimin rolü: Sağlık sektöründe bir araştırma. Kara Harp Okulu Bilim Dergisi, 23(2), 101-124.

Von Krogh, G., Ichijo, K., \& Nonaka, I. (2000). Enabling knowledge creation: How to unlock the mystery of tacit knowledge and release the power of innovation. Oxford University Press on Demand.

Wisse, B., Barelds, D. P., \& Rietzschel, E. F. (2015). How innovative is your employee? The role of employee and supervisor Dark Triad personality traits in supervisor perceptions of employee innovative behavior. Personality and Individual Differences, 82, 158-162.

Youndt, M. A., Snell, S. A., Dean Jr, J. W., \& Lepak, D. P. (1996). Human resource management, manufacturing strategy, and firm performance. Academy of Management Journal, 39(4), 836-866.

Yunus, O. M., Bustaman, H. A., \& Rashdi, W. F. A. W. M. (2014). Conducive business environment: Local government innovative work behavior. Procedia-Social and Behavioral Sciences, 129, 214220.

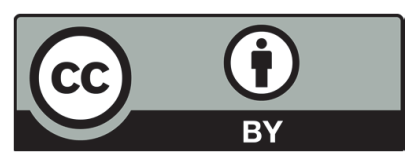

(C) 2019 by the authors; licensee Growing Science, Canada. This is an open access article distributed under the terms and conditions of the Creative Commons Attribution (CCBY) license (http://creativecommons.org/licenses/by/4.0/). 